\title{
Effects of fullerenol nanoparticles on kidney tissue in sevoflurane-treated rats
}

\author{
Sivgin $\mathrm{V}^{1}$, Yalcin $\mathrm{G}^{1}$, Kucuk $\mathrm{A}^{2}$, Sezen $\mathrm{SC}^{3}$, Afandiyeva $\mathrm{N}^{4}$, Arslan $\mathrm{M}^{5}$ \\ Gazi University School of Medicine, Department of Anaesthesiology and Reanimation, Ankara, Turkey. \\ mustarslan@gmail.com
}

\section{ABSTRACT}

AIM: The aim of this study is to demonstrate whether fullerenol C60 protects renal injury in sevoflurane-administered rats.

METHOD: Rats (n: 24) were randomly divided into four groups: Control (Group C), Fullerenol C60 (Group F), Sevoflurane (Group S), Fullerenol C60-Sevoflurane (Group FS). Thirty minutes before the procedure, Fullerenol C60, $100 \mathrm{mg} / \mathrm{kg}$, was administered intraperitoneally. Sevoflurane (2.3\%) was applied for 3 hours to rats in S and FS groups. Biochemical and histopathological parameters were analyzed in renal tissue samples. Kruskal-Wallis and Mann-Whitney $U$ tests were used in statistical analyzes.

RESULTS: Malondialdehyde (MDA) level and catalase (CAT) enzyme activity in Group S were significantly higher than that in all other groups. Paraoxanase (PON) enzyme activity in Group S was significantly lower than in Groups C and FS. The histopathological examination showed that vascular vacuolization and hypertrophy (VVH) and lymphocyte infiltration (LI) were significantly higher in the Group S compared to the Group C.

CONCLUSION: Renal histopathology revealed that the administration of Fullerenol C60 prior to sevoflurane inhalation reduced oxidative stress and partially corrected the damage caused by anesthesia. We concluded that Fullerenol $\mathrm{C} 60$ has a renal protective effect in rats when administered before sevoflurane anesthesia (Tab. 2, Fig. 4, Ref. 40). Text in PDF www.elis.sk.

KEY WORDS: fullerenol C60, sevoflurane, renal injury, MDA, PON-1.

\section{Introduction}

Fullerenol $\mathrm{C} 60(\mathrm{OH})$ is a water-soluble analog of fullerene and forms polyanion nanoparticles (1). In vivo and in vitro studies demonstrated that polyhydroxylated fullerenes had high antioxidative activity (2-4). It was shown that the fullerene-related antioxidant action depends on reorganization of double $\pi$ bonds on the surface of the molecule. Beside this high antioxidant effects, studies reported that fullerenes demonstrate radical scavenging activity, anti-genotoxic effect and protection against drug-induced toxicity (2-9).

Sevoflurane, the most preferred inhaled agent in anesthesia maintenance, is a halogenated anesthetic, and has favorable physiochemical and pharmaco-dynamic properties. Its low blood solubility facilitates rapid induction and recovery from anesthesia, thus

${ }^{1}$ Gazi University School of Medicine, Department of Anaesthesiology and Reanimation, Ankara, Turkey, ${ }^{2}$ Kütahya Health Science University School of Medicine, Department of Physiology, Kütahya, Turkey, ${ }^{3}$ Kirikkale University School of Medicine, Department of Histology and Embryology, Kirikkale, Turkey, and ${ }^{4}$ Gazi University School of Medicine, Department of Medical Biochemistry, Ankara, Turkey

Address for correspondence: M. Arslan, Dr, Gazi University School of Medicine, Department of Anaesthesiology and Reanimation, 06510 Ankara, Turkey. Phone: 90.533.42285 77

Acknowledgements: This study was supported by Gazi University Scientific Research Committee (Scientific Research Project No. 01/2019-42). providing a better control of anesthetic depth during the maintenance when compared to other commonly used volatile agents (10, 11). In both animals and humans, the biotransformation of sevoflurane by the hepatic microsomal (cytochrome P450) enzyme system results in generating inorganic fluoride ions, which in turn are capable of producing hepatic and especially renal toxicity $(12,13)$. Moreover, upon contact with alkaline $\mathrm{CO}_{2}$ absorbents (particularly those containing potassium hydroxide), sevoflurane is degraded to compound A (fluoromethyl-2,2-difluoro-1-(trifluoromethyl) vinyl ether) and when inhaled, it is nephrotoxic in rats (14-16). It also has been associated with changes in biochemical markers of renal injury in humans (17-20). There are numerous studies aimed at examining sevoflurane's hepato- and nephrotoxic potential in humans $(13,17-30)$ and several laboratory animal species $(15,16,31,32)$ but there have been no studies focused on investigating the influence of fullerenols on sevoflurane anesthesia-related renal injury.

In the present study we aimed to investigate the effects of fullerenols on sevoflurane associated renal injury in a rat model.

\section{Material and methods}

The present study was carried out in the Experimental Animals Laboratory of the Gazi University Medical Faculty (Ankara, Turkey), and was approved by the Gazi University Ethics Committee of Experimental Animals. All methods were in accordance with 


\section{$117-121$}

the Guide for the Care and Use of Laboratory Animals (Guide for the Care and Use of Laboratory Animals published by the United States National Institutes of Health, NIH Publication no. 85-23, revised, 1996).

Twenty-four male Wistar rats weighing 250-330 grams were used in this study. Rats were kept in separate cages, at a 12-hour light and dark cycle at room temperature $\left(24^{\circ} \mathrm{C}\right)$. They had free access to standard rat chow and water. The rats were randomly divided into four groups: Control (Group C), Fullerenol C60 (Group F), Sevoflurane (Group S), Fullerenol C60-Sevoflurane (Group FS). Before inducing the anesthesia, namely 30 minutes before the procedure, $100 \mathrm{mg} / \mathrm{kg}$ intraperitoneal nanoparticle was administered and sevoflurane $2.3 \%$ was applied to rats in S and FS groups for 3 hours. Renal tissue samples were taken at the end of the anesthesia period.

\section{Processing and preparation of tissue}

The tissue specimens were rapidly excised, washed in icecold normal saline, blotted, frozen in liquid nitrogen, and stored at $-80{ }^{\circ} \mathrm{C}$ until use. $10 \%(\mathrm{w} / \mathrm{v})$ homogenization of kidney tissues was done in Tris- $\mathrm{HCl}(0.1 \mathrm{M}, \mathrm{pH}$ 7.4) using an ice-chilled glass homogenizing vessel in a homogenizer fitted at $15,000 \mathrm{rpm}$. The suspended mixture was centrifuged at $1,000 \mathrm{~g}$ for $10 \mathrm{~min}$ at $4{ }^{\circ} \mathrm{C}$ in a refrigerated centrifuge.

\section{Kidney malondialdehyde (MDA) level assay}

The extent of lipid peroxidation was determined as the concentration of thiobarbituric acid reactive substances (TBARS) according to the method of Ohkawa et al (33). Briefly, $100 \mu \mathrm{L}$ of kidney homogenates or MDA standards were pipetted into test tubes containing $1.5 \mathrm{~mL}$ of $20 \%(\mathrm{w} / \mathrm{v})$ glacial acetic acid ( $\mathrm{pH} 3.5)$, $200 \mu \mathrm{L}$ of $8.1 \%$ (w/v) sodium dodecyl sulphate (SDS), $1.5 \mathrm{~mL}$ of $0.8 \%(\mathrm{w} / \mathrm{v})$ thiobarbituric acid (TBA) and $250 \mu \mathrm{L}$ of distilled water. The test tubes were incubated at $95^{\circ} \mathrm{C}$ for 60 minutes with a marble on top of each test tube. After incubation, the test tubes were cooled and then centrifuged at $4,000 \times \mathrm{g}$ for 10 minutes. The amount of MDA formed was measured spectrophotometrically at $532 \mathrm{~nm}$. 1,1,3,3-Tetraethoxypropane (TEP), a form of MDA, was used as standard in this assay. TBARS concentration was expressed as nmol of MDA per mg protein.

\section{Kidney catalase (CAT) enzyme activity assay}

A calorimetrically enzymatic assay kit at $405 \mathrm{~nm}$ (ZellBio $\mathrm{GmbH}$, Ulm, Germany) was used to measure CAT activity. The amount of the sample that contributes to decomposition of $1 \mu \mathrm{mol}$ of $\mathrm{H}_{2} \mathrm{O}_{2}$ to water and $\mathrm{O}_{2}$ in one minute is considered as one CAT activity unit. The sensitivity of this assay is about $0.5 \mathrm{U} / \mathrm{mL}$.

\section{Paraoxanase (PON) enzyme activities}

PON enzyme activity was determined spectrophotometrically at $25^{\circ} \mathrm{C}$ using diethyl p-nitrophenyl phosphate (paraoxon; $1 \mathrm{mM}$ ) in $50 \mathrm{mM}$ glycine $/ \mathrm{NaOH}$ (pH 10.5) containing $1 \mathrm{mM} \mathrm{CaCl}_{2}$. The enzyme assay was based on the estimation of p-nitrophenol at 412 $\mathrm{nm}$. The molar extinction coefficient of p-nitrophenol ( $\mathrm{e}=18,290$ $\mathrm{M}^{-1} \mathrm{~cm}^{-1}$ at $\mathrm{pH} 10.5$ ) was used to calculate the enzyme activity. One enzyme unit was defined as the amount of enzyme that catalyzed the hydrolysis of $1 \mu \mathrm{mol}$ of substrate at $25^{\circ} \mathrm{C}$.

\section{Histological determinations}

All of the specimens were fixed in $10 \%$ buffered neutral formalin and embedded in paraffin. To visualize myocardial lesions at different levels, the entire heart was cut into four segments from apex to bottom. The segments were embedded in paraffin and $4-\mu \mathrm{m}$ thickness cross-sections were cut from each segment. The slides were stained with Hematoxylin-Eosin (Bio-optica, Milano, Italy) for the evaluation of the tissues' histological features.

\section{Statistical analysis}

SPSS version 20.0 (IBM Corp., Armonk, NY, USA) was used for statistical analysis. The differences between groups were as-

Tab. 1. Data regarding oxidative status of renal tissue (mean $\pm \mathrm{SD}$ ).

\begin{tabular}{lcccr}
\hline & $\begin{array}{c}\text { Group C } \\
(\mathrm{n}=6)\end{array}$ & $\begin{array}{c}\text { Group F } \\
(\mathrm{n}=6)\end{array}$ & $\begin{array}{c}\text { Group S } \\
(\mathrm{n}=6)\end{array}$ & $\begin{array}{c}\text { Group FS } \\
(\mathrm{n}=6)\end{array}$ \\
\hline MDA (nmol/mg protein) & $1.21 \pm 0.14^{*}$ & $1.07 \pm 0.15^{*}$ & $2.31 \pm 0.65$ & $0.97 \pm 0.17 *$ \\
CAT (IU/mg protein) & $1463.60 \pm 144.88^{*}$ & $1687.40 \pm 120.24 *$ & $2124.25 \pm 152.99$ & $1416.60 \pm 98.58^{*}$ \\
PON (IU/mg protein) & $723.83 \pm 61.03^{*}$ & $655.00 \pm 35.05$ & $520.50 \pm 51.65$ & $671.00 \pm 40.95^{*}$ \\
\hline
\end{tabular}

p**: Kruskal-Wallis $\mathrm{p}<0.05, * \mathrm{p}<0.05$ : Compared to Group $\mathrm{S}$

Tab. 2. Histopathological data of renal tissue (mean \pm SD).

\begin{tabular}{|c|c|c|c|c|c|}
\hline & $\begin{array}{c}\text { Group C } \\
(n=6)\end{array}$ & $\begin{array}{c}\text { Group F } \\
(n=6)\end{array}$ & $\begin{array}{c}\text { Group S } \\
(n=6)\end{array}$ & $\begin{array}{c}\text { Group FS } \\
(n=6)\end{array}$ & $\mathrm{p}^{* *}$ \\
\hline Glomerular vacuolization (GV) & $0.33 \pm 0.21$ & $0.67 \pm 0.21$ & $0.83 \pm 0.31$ & $0.67 \pm 0.21$ & 0.523 \\
\hline Tubular dilation (TD) & $0.33 \pm 0.21$ & $0.67 \pm 0.21$ & $0.83 \pm 0.31$ & $0.67 \pm 0.21$ & 0.523 \\
\hline Vascular vacuolization and hypertrophy (VVH) & $0.17 \pm 0.17^{*}$ & $0.67 \pm 0.21$ & $1.17 \pm 0.31$ & $0.50 \pm 0.22$ & 0.045 \\
\hline Tubular cell degeneration and necrosis (THDN) & $0.33 \pm 0.21$ & $0.67 \pm 0.21$ & $0.83 \pm 0.17$ & $0.83 \pm 0.17$ & 0.235 \\
\hline Bowman space dilation (BSD) & $0.50 \pm 0.22$ & $0.50 \pm 0.22$ & $0.67 \pm 0.21$ & $0.67 \pm 0.21$ & 0.927 \\
\hline Tubular hyaline cylinder cell (THS) & $0.50 \pm 0.22$ & $0.67 \pm 0.21$ & $0.83 \pm 0.17$ & $0.67 \pm 0.21$ & 0.724 \\
\hline Tubular cell loss (THD) & $0.33 \pm 0.21$ & $0.67 \pm 0.21$ & $0.83 \pm 0.31$ & $0.83 \pm 0.31$ & 0.508 \\
\hline
\end{tabular}

p**: Kruskal-Wallis test $\mathrm{p}<0.05,{ }^{*} \mathrm{p}<0.05$ : Compared to Group S 
sessed using the Kruskal-Wallis test with a post-hoc Bonferroniadjusted Mann-Whitney U-test. Values are expressed as mean \pm standard deviation (SD). $\mathrm{p}<0.05$ was considered to indicate a statistically significant difference.

\section{Results}

Malondialdehyde levels in Group S were significantly higher than those in all other groups $(\mathrm{p}=0.039, \mathrm{p}=0.021, \mathrm{p}=0.013$, respectively). MDA levels in Group FS and Group C were similar $(p=0.624)$. CAT enzyme activity in Group S was significantly

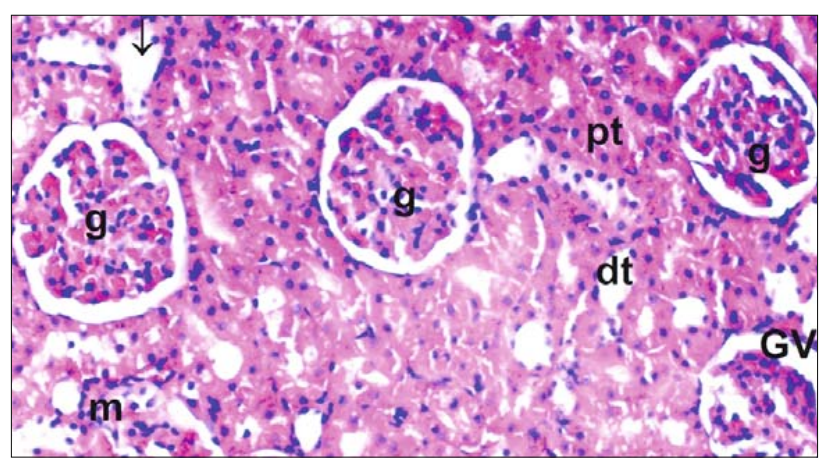

Fig. 1. Control Group (g: glomerulus, dt: distal tubule, pt: proximal tubule, m: macula densa, dt: dilated tubule, GV: vacuolization).

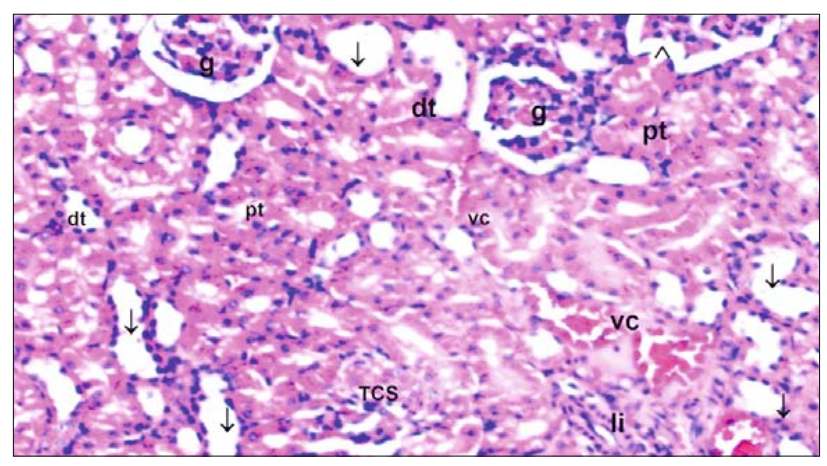

Fig. 2. Fullerenol Group (g: glomerulus, dt: distal tubule, pt: proximal tubule, m: macula densa, dt: dilated tubule, li: lymphoid infiltration, vc: vascular congestion, TCS: tubular cell spillage).

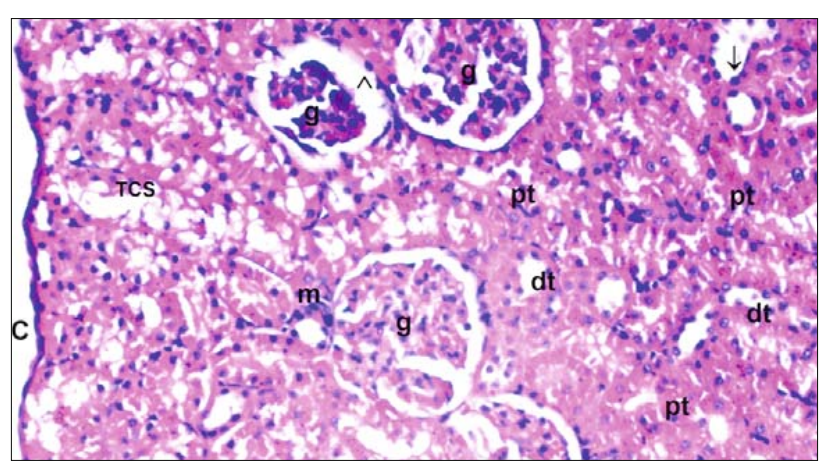

Fig. 3. Sevoflurane Group (g: glomerulus, dt: distal tubule, pt: proximal tubule, m: macula densa, dt: dilated tubule, li: lymphoid infiltration, vc: vascular congestion, TCS: tubular cell spillage).

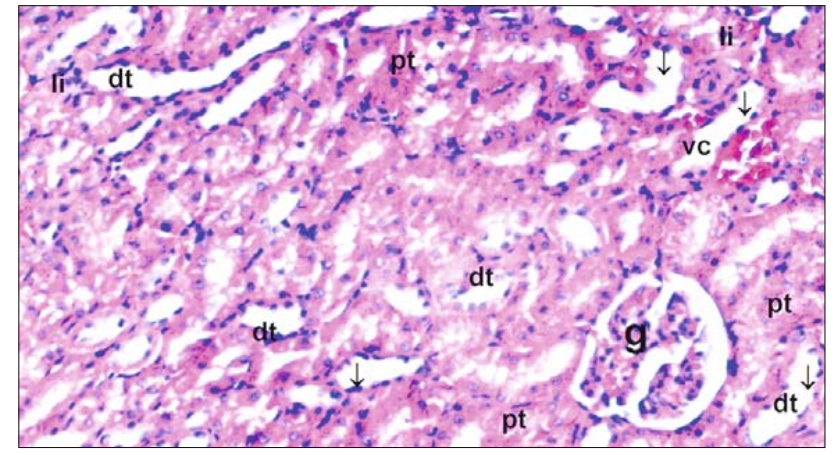

Fig. 4.: Fullerenol-sevoflurane Group (g: glomerulus, dt: distal tubule, pt: proximal tubule, m: macular densa, dt: dilated tubule, li: lymphoid infiltration, ve: vascular congestion, TCS: tubular cell spillage).

higher than that in all other groups $(\mathrm{p}=0.003, \mathrm{p}=0.035, \mathrm{p}=0.002$, respectively) (Tab. 1).

The comparison of CAT enzyme activity between Group C and Group FS showed similar results $(p=0.795)$. PON enzyme activity in Group $\mathrm{S}$ was significantly lower than in groups $\mathrm{C}$ and FS ( $p=0.007, p=0.039$, respectively). However, the comparison of PON levels between groups $\mathrm{C}$ and FS did not show any significant difference $(p=0.447)($ Tab. 1).

The histopathological examination showed that vascular vacuolization and hypertrophy (VVH) and lymphocyte infiltration (LI) were significantly higher in Group S compared to Group C $(p=0.006, p=0.004)($ Tab. 2, Figs 1-4). The administration of Fullerenol $\mathrm{C} 60$ before sevoflurane administration was not statistically significant (Tab. 2).

\section{Discussion}

The examination of the protective effect of fullerenols on sevoflurane-related renal injury showed that pretreatment with $100 \mathrm{mg} / \mathrm{kg}$ intraperitoneal fullerenol effectively decreased renal injury in sevoflurane-administered rats. Sevoflurane, the potent volatile anesthetic undergoes degradation both in vivo and in vitro. The metabolism produces inorganic fluoride (21) and the reaction with carbon dioxide absorbents produces the compound A (34). Both degradation products can damage rat kidneys (14). The concentration of compound $\mathrm{A}$ and the duration of exposure to compound A determine the extent of renal injury in rats (35). The threshold for nephrotoxicity seems to be three hours of sevoflurane exposure. In the present study, the rats were administered with sevoflurane for 3 hours and we sought to determine whether fullerenol was an effective agent against sevoflurane-related renal injury.

Srdjenovic et al (36) demonstrated that fullerenol given in a dose of $100 \mathrm{mg} / \mathrm{kg}$ could antagonize doxorubicin-induced toxicity in lungs, kidneys, and testes of rats. Based on their findings, our study was designed to test whether the fullerenol in a dose of $100 \mathrm{mg} / \mathrm{kg}$ protects against kidney tissue damage related to sevoflurane inhalation. The results of this study showed that fullerenol administered intraperitoneally 30 minutes before sevoflurane 
$117-121$

inhalation in rats reduced oxidative stress and partially corrected the damage caused by anesthesia in renal histopathology.

Malondialdehyde is one of the best-investigated products of lipid peroxidation. Lipid peroxidation products, including MDA, are produced from polyunsaturated fatty acids (PUFAs) by both chemical reactions and re-actions catalyzed by enzymes. (37). MDA is the prototype of the TBARS and it is the most frequently measured biomarker of oxidative stress, namely of lipid peroxidation. In many diseases, higher concentrations of MDA are measured in biological samples as compared to healthy individuals. Therefore, the elevated oxidative stress is generally regarded as a pathological condition. In the present study, the extent of damage in kidney was measured by MDA levels in rat renal tissues.

Catalase is a type of conjugate that uses iron porphyrin as its prosthetic group and has a strong radical scavenging function that can protect the tissues from oxidative damage (38). With the action of CAT, $\mathrm{H}_{2} \mathrm{O}_{2}$ transforms into water and $\mathrm{O}_{2}$, thus preventing $\mathrm{H}_{2} \mathrm{O}_{2}$ from reacting with $\mathrm{O}_{2}^{-}$and producing $\mathrm{OH}^{-}$in the presence of iron-chelating agents (39). When CAT inactivates $\mathrm{H}_{2} \mathrm{O}_{2}$, its consumption increases and thereby causes the deterioration of its activity. The results of this study indicated that the CAT content of renal tissue was significantly reduced following fullerenol treatment when compared with the group that received only sevoflurane.

Paraoxonases compose a family with three members (Paraoxonases 1,2, and 3) that have various roles in multiple biochemical pathways including inflammation. Paraoxonase 1 (PON-1) is the most studied enzyme of the family. Therefore, in this study, PON1 levels in the renal tissues were used to determine the protective effects of fullerenol. PON-1 plays a significant role in delaying/ inhibiting the oxidation and in preventing the accumulation of lipid peroxides (40). The results of this study suggested that antioxidant activity of PON-1 was an important factor which provided protection from oxidative stress and lipid peroxidation against sevoflurane-related renal injury.

\section{Conclusion}

Our results confirm a satisfactory nephroprotective efficacy of fullerenol in the acute phase of sevoflurane-related renal toxicity and encourage further studies regarding its use as a potential nephroprotector.

\section{References}

1. Wilson SR, Yurchenko ME, Schuster DI. Synthesis of Fluorous Fullerene Adducts: Reversible Solubilization of Fullerenes in Perfluorinated Solvents. J Org Chem 2000; 65: 2619-2623.

2. Djordjevic A, Canadanovic-Brunet J, Vojinovic-Miloradov M, Bogdanovic G. Antioxidant properties and hypothetical radical mechanism of fullerenol $\mathrm{C}_{60}(\mathrm{OH})_{24}$. Oxi Commun 2005; 27: 213-218.

3. Andrievsky GV, Bruskov VI, Tykhomyrov AA, Gudkov SV. Peculiarities of the antioxidant and radioprotective effects of hydrated C60 fullerene nanostuctures in vitro and in vivo. Free Radic Biol Med 2009; 47: 786-793.

4. Yin JJ, Lao F, Fu PP, Kanakamma PP, Shen CKF, Luh TY. The scavenging of reactive oxygen species and the potential for cell protection by functionalized fullerene materials. Biomaterials 2009; 30: 611-621.
5. Bogdanović G, Kojić V, Dordević A, Canadanović-Brunet J, Vojinović-Miloradov M, Baltić VV. Modulating activity of fullerenol $\mathrm{C}_{60}(\mathrm{OH})_{22}$ on doxorubicin-induced cytotoxicity. Toxicol In Vitro 2004; 18: 629-637.

6. Trajković S, Dobrić S, Jačević V, Dragojević-Simić V, Milovanović Z, Đordevic A. Tissue protective effects of fullerenol $\mathrm{C}_{60}(\mathrm{OH})_{24}$ and amifostine in irradiated rats. Colloids Surf B Biointerfaces 2007; 58: 39-43.

7. Bogdanović V, Stankov K, Ičević I, Žikić D, Šolajić S, Djordjevic A et al. Fullerenol $\mathrm{C}_{60}(\mathrm{OH})_{24}$ effects on antioxidative enzymes activity in irradiated human erythroleukemia cell line. J Radiat Res 2008; 49: 321-327.

8. Injac R, Perse M, Boskovic M, Djordjevic-Milic V, Djordjevic A, Hvala A et al. Cardioprotective effects of fullerenol $\mathrm{C}_{60}(\mathrm{OH})_{24}$ on a single dose doxorubicin-induced cardiotoxicity in rats with malignant neoplasm. Technol Cancer Res Treat 2008; 7: 15-25.

9. Injac R, Radic N, Govedarica B, Perse M, Cerar A, Djordjevic A, Strukelj B. Acute doxorubicin pulmotoxicity in rats with malignant neoplasm is effectively treated with fullerenol $\mathrm{C}_{60}(\mathrm{OH})_{24}$ trough inhibition of oxidative stress. Pharmacol Rep 2009; 61: 335-342.

10. Eger EI. New inhaled anesthetics. Anesthesiology 1994; 80: 906-922.

11. Dudziak R, Behne M. Uptake and distribution of sevoflurane. Anaesthesist 1998; 47: 1-6.

12. Karasch ED, Thummel KE. Identification of cytochrome P450 2EI as the predominant enzyme catalyzing human liver microsomal defluorination of sevofluorane, isofluorane and methoxyfluorane. Anesthesiology 1993; 79: 795-807.

13. Kharasch ED, Karol MD, Lanni C, Sawchuk R. Clinical sevoflurane metabolism and disposition. I. Sevoflurane and metabolite pharmacokinetics. Anesthesiology 1995; 82: 1369-1378.

14. Morio M, Fujii K, Satoh N, Imai M, Kawakami U, Mizuno T et al. Reaction of sevoflurane and its degradation products with soda lime. Toxicity of the by products. Anesthesiology 1992; 77: 1155-1164.

15. Keller KA, Callan C, Prokocimer P, Delgado-Herrera L, Friedman MB, Hoffman GM et al. Inhalation toxicity study of a haloalkene degradant of sevoflurane, Compound A (PIFE), in Sprague-Dawley rats. Anesthesiology 1995; 83: 1220-1232.

16. Behne M, Wilke HJ, Harder S. Clinical pharmacokinetics of sevoflurane. Clin Pharmacokinet 1999; 36: 13-26.

17. Higuchi H, Sumikura H, Sumita S, Arimura S, Takamatsu F, Kanno $M$ et al. Renal function in patients with high serum fluoride concentrations after prolonged sevoflurane anesthesia. Anesthesiology 1995; 83 : 449-458.

18. Higuchi H, Sumita S, Wada H, Ura T, Ikemoto T, Nakai T et al. Effects of sevoflurane and isoflurane on renal function and on possible markers of nephrotoxicity. Anesthesiology 1998; 89: 307-322.

19. Eger EI II, Koblin DD, Bowland T, Ionescu P, Laster MJ, Fang Z et al. Nephrotoxicity of sevoflurane vs desflurane anesthesia in volunteers. Anesth Analg 1997; 84: 160-168.

20. Goldberg ME, Cantillo J, Gratz I, Deal E, Vekeman D, McDougall R et al. Dose of compound A, not sevoflurane, determines changes in the biochemical markers of renal injury in healthy volunteers. Anesth Analg 1999; 88: 437-445.

21. Frink EJ Jr, Ghantaous H, Malan T, Morgan S, Fernando J, Gandolfi AJ et al. Plasma inorganic fluoride with sevoflurane anesthesia: correlation with indices of hepatic and renal function. Anesth Analg 1992; 74: $231-235$. 
22. Frink EJ Jr, Green WB Jr, Brown EA, Malcomson M, Hammond LC, Valencia FG et al. Compound A concentrations during sevoflurane anesthesia in children. Anesthesiology 1996; 84: 566-571.

23. Bito H, Ikeda K. Plasma inorganic fluoride and intracircuit degradation product concentrations in long-duration, low-flow sevoflurane anesthesia. Anesth Analg 1994; 79: 946-951.

24. Bito H, Ikeda K. Long-duration, low-flow sevoflurane anesthesia using two carbon dioxide absorbents. Quantification of degradation products in the circuit. Anesthesiology 1994; 81: 340-345.

25. Bito H, Ikeda K. Renal and hepatic function in surgical patients after low-flow sevoflurane or isoflurane anesthesia. Anesth Analg 1996; 82: 173-176.

26. Kharasch ED, Frink EJ Jr, Zagar R, Bowdle TA, Artru A, Nogami WM. Assessment of low-flow sevoflurane and isoflurane effects on renal function using sensitive markers of tubular toxicity. Anesthesiology 1997; 86: 1238-1253.

27. Kharasch ED, Frink EJ Jr, Artru A, Michalowski P, Rooke GA, Nogami W. Long-duration low-flow sevoflurane and isoflurane effects on postoperative renal and hepatic function. Anesth Analg. 2001; 93: $1511-15120$.

28. Bito H, Ikeuchi Y, Ikeda K. Effects of low-flow sevoflurane anesthesia on renal function: comparison with high-flow sevoflurane anesthesia and low-flow isoflurane anesthesia. Anesthesiology 1997; 86: 1231-1237.

29. Groudine SB, Fragen RJ, Kharasch ED, Eisenman TS, Frink EJ, McConnell S. Comparison of renal function following anesthesia with low-flow sevoflurane and isoflurane. J Clin Anesth 1999; 11: 201-207.

30. Obata R, Bito H, Ohmura M, Moriwaki G, Ikeuchi Y, Katoh T et al. The effects of prolonged low-flow sevoflurane anesthesia on renal and hepatic function. Anesth Analg 2000; 91: 1262-1268.
31. Kharasch ED, Thorning D, Garton K, Hankins DC, Kilty CG. Role of renal cysteine conjugate b-lyase in the mechanism of Compound A nephrotoxicity in rats. Anesthesiology 1997; 86: 160-171.

32. Martis L, Lynch S, Napoli MD, Woods EF. Biotransformation of sevoflurane in dogs and rats. Anesth Analg 1981; 60: 186-191.

33. Ohkawa H, Ohishi N, Yagi K. Assay for lipid peroxides in animal tissues by thiobarbituric acid reaction. Anal Biochem 1979; 95: 351-358.

34. Wallin RF, Regan BM, Napoli MD, Stern IJ. Sevoflurane: a new_inhalational_anesthetic agent. Anesth Analg 1975; 54: 758-766.

35. Gonsowski CT, Laster MJ, Eger EI 2nd, Ferrell LD, Kerschmann RL. Toxicity of compound A in rats. Effect of a 3-hour administration. Anesthesiology 1994; 80: 556-565.

36. Srdjenovic B, Milic-Torres V, Grujic N, Stankov K, Djordjevic A, Vasovic V. Antioxidant properties of fullerenol $\mathrm{C}_{60}(\mathrm{OH})_{24}$ in rat kidneys, testes, and lungs treated with doxorubicin. Toxicol Mech Methods 2010; 20: 298-305.

37. Tsikas D. Assessment of lipid peroxidation by measuring malondialdehyde (MDA) and relatives in biological samples: Analytical and biological challenges. Anal Biochem 2017; 524: 13-30.

38. Njuma OJ, Ndontsa EN, Goodwin DC. Catalase in peroxidase clothing: Interdependent cooperation of two cofactors in the catalytic versatility of KatG. Arch Biochem Biophys 2014; 544: 27-39.

39. Yoshida K, Okabe E. Selective impairment of endothelium-dependent relaxation by sevoflurane: oxygen free radicals participation. Anesthesiology 1992; 76: 440-447.

40. Reichert CO, de Macedo CG, Levy D, Sini BC, Monteiro AM, Gidlund $\mathbf{M}$ et al. Paraoxonases (PON) 1, 2, and 3 Polymorphisms and PON-1 Activities in Patients with Sickle Cell Disease. Antioxidants 2019; 8252: 1-13. 